\title{
Del anfifascismo al antiperonismo: Argentina Libre, ...Antinazi y el surgimiento del antiperonismo político e intelectual ${ }^{1}$
}

\author{
JORGE NÁLLIM \\ Sarah Lawrence College
}

A principios de 1940, la Argentina atravesaba un periodo particularmente turbulento de su historia. Los conflictos políticos derivados de la crisis de la limitada restauración democrática iniciada en 1932 se profundizaban debido al impacto de la Segunda Guerra Mundial en los debates ideológicos y partidarios locales. En lo económico, la guerra generaba nuevos desafíos para un país que había experimentado intensas transformaciones en la década anterior, reflejadas en la creciente intervención del estado en la economía y el sostenido avance de la industrialización, principalmente alrededor de la ciudad de Buenos Aires. Asimismo, estas transformaciones generaban tensiones en la estructura social del país, entre ellas, el crecimiento significativo de un sector obrero movilizado y con mayores demandas.

En este contexto, en marzo de 1940 aparecía en la ciudad de Buenos Aires un nuevo semanario, Argentina Libre, cuya publicación entre 1940 y 1943 abriría una importante experiencia editorial y política continuada por ...Antinazi en 1945-1946 y una segunda época de Argentina Libre en 1946-1949. El análisis de ambas publicaciones en su periodo de mayor relevancia, desde su fundación hasta la victoria de Juan Perón en las elecciones de febrero de 1946, es el objetivo del presente capítulo, y se justifica por diversas razones. En primer lugar, sus páginas acogieron a destacados intelectuales y a líderes de los más importantes partidos políticos de los años 30 y 40. De este modo, Argentina Libre se constituyó en un ámbito para la consolidación de vínculos personales, políticos e ideológicos forjados en los años anteriores. A pesar de esta relevancia, muy pocos trabajos han prestado atención detallada a ambas publi-

Agradezco los comentarios de Flavia Fiorucci, Marcela García y Eduardo Zimmermann. 
caciones, salvo referencias esporádicas a su rol como núcleos antifascistas, pro-aliados y anti-peronistas. ${ }^{2}$

En segundo lugar, el análisis más detallado de estos semanarios permite conocer en toda su amplitud el importante rol que cumplieron en los años que vieron nacer al peronismo. Argentina Libre proclamó desde sus inicios una postura militante orientada hacia dos objetivos básicos: en el ámbito nacional, la defensa de una democracia efectiva; en el ámbito internacional, el apoyo hacia los aliados en la Segunda Guerra Mundial. Con el tiempo, estos objetivos llevaron a la publicación a convertirse en un verdadero espacio editorial, social e ideológico para aquellos grupos que se autodefinían como la oposición democrática liberal al gobierno nacional dominado por los grupos conservadores. Basándose en estos principios, y consolidando relaciones pre-existentes, Argentina Libre asumió el rol de vocero para la formación de la primera Unión Democrática en 1942, objetivo frustrado por divisiones internas y, fundamentalmente, por el gobierno militar surgido del golpe del 4 de junio de 1943. Los mismos sectores que habían participado en Argentina Libre se reagruparon en ...Antinazi en febrero de 1945, que reunió a los variados sectores que compartían su vehemente oposición al régimen militar y Perón y quienes propiciaron la formación de la Unión Democrática a fines de 1945 .

En este sentido, el análisis de Argentina Libre y ...Antinazi revela el proceso de construcción de la oposición intelectual y política al Peronismo entre 1940 y 1946 desde una perspectiva más amplia. Este proceso no fue lineal, y las coincidencias entre los grupos que colaboraban en ambas publicaciones frecuentemente se vieron perturbadas por tensiones y disidencias. La primera sección de este estudio analiza la trayectoria de Argentina Libre en 19401943, mientras que la segunda se enfoca en ...Antinazi en el contexto del régimen militar de junio de 1943 y el surgimiento del movimiento peronista en 1945-1946.

\section{Por la democracia y el antifascismo: Argentina Libre y la primera Unión Democrática, 1940-1943}

La creación de Argentina Libre debe comprenderse en el contexto político de principios de 1940, en el marco de la crisis del sistema de democracia restringida que había surgido del golpe militar de septiembre de 1930 y del Gobierno Provisional del general José Uriburu y que había sido inaugurado

2 Como excepción, el trabajo de Bisso (2001). 
por Agustín P. Justo en $1932 .{ }^{3}$ En un contexto caracterizado por la fragmentación política, este sistema se basaba en la alianza y colaboración legislativa, conocida con el nombre de Concordancia, de socialistas independientes, radicales antipersonalistas y grupos conservadores provinciales agrupados en el Partido Demócrata Nacional. Este esquema se completaba con el apoyo de las fuerzas armadas -fundamentalmente el ejército-y la Iglesia Católica a los grupos en el poder, y con la aplicación selectiva pero decisiva del fraude electoral, que se intensificó a partir de 1935 cuando la Unión Cívica Radical levantó su abstención electoral para enfrentar a Justo y su coalición.

El retorno del radicalismo a la arena electoral movió a Justo y al gobierno hacia la derecha en 1935-1936, provocando que los grupos más conservadores de la Concordancia adquirieran mayor peso y relevancia. Este giro a la derecha se manifestó en la tolerancia oficial hacia el retorno del fraude electoral a gran escala en las elecciones de Buenos Aires y Mendoza en 1935-1936 y en las presidenciales de 1937. Al mismo tiempo, la Concordancia propició en el Congreso una serie de leyes que agitaron los conflictos políticos, tales como la intervención a la provincia de Santa Fe -gobernada por la oposición demócrata progresista desde 1931-, la eliminación de las minorías en los colegios electorales y el proyecto de represión del comunismo. Estos proyectos fueron defendidos por senadores conservadores tales como Benjamín Villafañe y Matías Sánchez Sorondo, quienes los fundamentaron en la crítica abierta a la democracia liberal basada en el voto universal y, en el caso de Sánchez Sorondo, en la defensa del fascismo. ${ }^{4}$ La elección fraudulenta de Manuel Fresco a la gobernación de Buenos Aires en 1936, quien defendía públicamente sus ideas nacionalistas y sus reservas frente al voto libre y secreto, se inscribe también en este giro hacia la derecha (Dolkart 1993: 84-86, Bitrán y Schneider 1991, Reitano 1992). Al mismo tiempo, el gobierno nacional apoyó y participó abiertamente del evento más importante de la movilización de la Iglesia Católica argentina, el Congreso Eucarístico de 1934, que fue seguido por la implantación de la educación católica obligatoria en las escuelas públicas de varias provincias regidas por los conservadores (Zanatta 1997: 95-236).

3 Un análisis detallado y actualizado de los desarrollos políticos e ideológicos entre 1930 y 1943 se puede consultar en los trabajos recopilados por Alejandro Cattaruzza (2001), en particular los de de Privitellio (2001: 97-142) y Macor (2001: 49-94). También son útiles los estudios de Halperin Dongui (2003 y 2004). Zuleta Álvarez (2001: 265-297), Romero (1999: 89-138), Cattaruza (1997) y de Privitellio (1997). Como referencia general, se pueden consultar los trabajos ya clásicos de Ciria (1985), Bejar (1983), Cantón, Moreno y Ciria (1986), Potash (1982) y Rouquié (1981).

4 Diario de Sesiones de la Cámara de Senadores (1935): II, 739-783 (1936): I,. 630-710, III, 24-707. 
Frente a esta posición, los partidos opositores radical, socialista y demócrata progresista invocaron la tradición liberal y democrática en contra de la Concordancia en el Congreso Nacional y en la prensa diaria, e incluso intentaron la formación de un Frente Popular democrático en 1936. El estallido de la Guerra Civil Española a mediados de 1936 contribuyó a profundizar las divisiones ideológicas y políticas. ${ }^{5}$ Por un lado, los defensores de la República representaban un heterogéneo grupo que incluía a radicales, socialistas, demócrata progresistas, comunistas, los escritores agrupados en las revistas Sur y Nosotros, los profesionales agrupados en el Colegio Libre de Estudios Superiores (CLES), los estudiantes universitarios de la Federación Universitaria Argentina (FUA) y los sindicatos y organizaciones obreras. Todos ellos coincidían en la defensa del antifascismo y la democracia y vinculaban el gobierno nacional a movimientos e ideologías antiliberales y antidemocráticos. Por su parte, la defensa de los franquistas atrajo no sólo a la Iglesia Católica y a grupos nacionalistas políticos e intelectuales de derecha sino también a destacados miembros de los grupos de la Concordancia.

En este contexto, la elección presidencial viciada de fraudes y violencias del radical antipersonalista Roberto Ortiz para el periodo 1938-1944 permitía suponer que la situación no cambiaría. Sin embargo, la Concordancia pronto se vio envuelta en un proceso de agudos conflictos internos. Ortiz manifestó su deseo de terminar con las prácticas políticas fraudulentas, y como parte de su programa decretó la intervención federal a principios de 1940 de dos provincias gobernadas por los conservadores, Buenos Aires y Catamarca. Esta política profundizó las divisiones en la coalición gobernante, alienando al vicepresidente y a los socios conservadores de Ortiz, quienes procedieron a atacar al gobierno nacional en el Congreso Nacional. Al mismo tiempo, Ortiz se ganaba la simpatía de la oposición política en el Congreso formada por radicales, socialistas y demócrata progresistas, favorecida por la posición neutral pero simpática hacia los aliados que el gobierno nacional adoptó frente al estallido de la Segunda Guerra Mundial.

El programa de Ortiz terminó abruptamente cuando un grave cuadro de enfermedad lo forzó, primero, a delegar la presidencia en el vicepresidente Castillo en julio de 1940 y, luego, a renunciar en junio de 1942 para morir un mes más tarde. Castillo, un conservador tradicional, no continuó con las políticas de Ortiz. En diciembre de 1940 y enero de 1941 el gobierno nacional toleró nuevamente elecciones fraudulentas en Santa Fe y Mendoza en beneficio de

5 El impacto de la Guerra Civil Española en Argentina se puede consultar en Quijada (1991), Trifone y Svarzman (1993), Falcolff (1982: 291-348), Goldar (1996), Pereyra (1976: 6-33) y Schwarztein (2001). 
los sectores conservadores de la Concordancia. Para apuntalar su posición política, Castillo también favoreció el sector de oficiales nacionalistas en el ejército concediéndole posiciones en el gobierno. La posición conservadora del gobierno se manifestó en otras medidas que la oposición política denunció como antidemocráticas, tales como la clausura del Concejo Deliberante de Buenos Aires en octubre de 1941 y la imposición del estado de sitio en diciembre de 1941.

En este enrarecido ambiente político, la posición de Castillo frente a la guerra mundial contribuyó a endurecer las líneas políticas e ideológicas. ${ }^{6} \mathrm{La}$ transición de Ortiz a Castillo tuvo lugar entre los meses de junio y julio de 1940, coincidiendo con la blitzkrieg nazi en Europa Occidental y la caída de París. Revirtiendo las posiciones iniciales de Ortiz, y apoyado por su ministro de Relaciones Exteriores, Enrique Ruiz Guiñazú, Castillo mantuvo tercamente la neutralidad argentina frente al conflicto, resistiendo las crecientes presiones de Estados Unidos para unirse a los aliados, especialmente después de Pearl Harbour. La irritación estadounidense se transformó en abierta confrontación cuando la Argentina influyó en la reunión de cancilleres americanos, reunida en Río de Janeiro en enero de 1942, para moderar el grado de adhesión oficial de los países latinoamericanos a los Estados Unidos y los aliados. La oposición política a Castillo unió las políticas internas y externas del gobierno, y las simplificó para denunciarlo como un régimen antidemocrático y favorable a los totalitarismos europeos.

En este contexto nació Argentina Libre, cuyo primer número vio la luz el 7 de marzo de 1940, el mismo día que Ortiz decretaba la intervención federal de la provincia de Buenos Aires. La publicación, de formato tabloide, aparecería hasta julio de 1943, cuando fue clausurada por el gobierno militar. Otros cinco números fueron publicados entre diciembre de 1944 y enero de 1945, cuando fue nuevamente clausurada. Reapareció en febrero de 1945 bajo el nombre de ...Antinazi hasta junio de 1946, cuando adoptó nuevamente el título Argentina Libre y que mantendría hasta junio de 1947. En total, entre 1940 y 1947 Argentina Libre/...Antinazi publicó 297 números, cubriendo años y eventos cruciales de la historia argentina (CEDINCI 2002: 3). El fundador y primer director de Argentina Libre fue Octavio González Roura, un abogado que presidió la Dirección Nacional de Turismo en 1941-1943, había dirigido en París la Revue Argentine bajo el seudónimo de Edmond de Narval, y participaba de otras organizaciones pro-aliadas tales como Acción Argentina, una organización

6 Además de la bibliografía ya mencionada en nota 3, el impacto concreto de la Segunda Guerra Mundial en la Argentina se puede consultar en Rapoport (1980), Newton (1995), y los trabajos compilados por Di Tella y Watts (1989). 
formada también a principios de 1940 cuyo objetivo era concretar los principios enunciados por Argentina Libre (Fitte y Sánchez Zinny 1944). Sin embargo, el principal responsable en la conducción era Luis Koiffman, quien estaba vinculado al Partido Socialista. La extracción política e ideológica de las personas e instituciones que participaron en Argentina Libre se puede apreciar en el siguiente cuadro, en el que se los compara con quienes participaban en Acción Argentina.

\section{CUADRO 1}

Lazos personales e institucionales de Argentina Libre, 1940-1943

\begin{tabular}{|c|c|c|}
\hline & Argentina Libre ${ }^{7}$ & Acción Argentina ${ }^{8}$ \\
\hline UCR & $\begin{array}{l}\text { Ernesto Boatti, Eduardo } \\
\text { Laurencena, Emilio Ravignani, } \\
\text { José Tamborini, Honorio } \\
\text { Pueyrredón. }\end{array}$ & $\begin{array}{l}\text { Marcelo T. de Alvear, Eduardo } \\
\text { Laurencena, Eduardo Araujo, } \\
\text { Ernesto Boatti, Emilio Ravignani, } \\
\text { Nerio Rojas, Santiago Nudelman, } \\
\text { Carlos Cisneros, Martín Noel } \\
\text { Carlos Rodríguez, José P. } \\
\text { Tamborini. }\end{array}$ \\
\hline PDP & Julio Noble, Juan J. Díaz Arana. & $\begin{array}{l}\text { Julio Noble, Juan J. Díaz Arana, } \\
\text { Raúl Monsegur, Horacio Thedy, } \\
\text { Honorio Roigt. }\end{array}$ \\
\hline PS & $\begin{array}{l}\text { Luis Koiffmann, Mario Bravo, } \\
\text { Nicolás Repetto, Américo } \\
\text { Ghioldi, Silvio Ruggieri, José } \\
\text { Luis Pena, Carlos Sanchez } \\
\text { Viamonte, Joaquín Neyra, José } \\
\text { Luis Romero, Guillermo Salazar } \\
\text { Altamira, Alberto Gerchunoff. }\end{array}$ & $\begin{array}{l}\text { Alfredo Palacios, Nicolás Repetto, } \\
\text { Mario Bravo, Américo Ghioldi, } \\
\text { Alicia Moreau de Justo, Juan A. } \\
\text { Solari, Guillermo Salazar Altamira, } \\
\text { Arturo Orgaz, Juan Valmaggia, } \\
\text { Silvio Ruggieri, Alberto } \\
\text { Gerchunoff, Juan A. Solari, } \\
\text { Manuel Palacín. }\end{array}$ \\
\hline
\end{tabular}

7 La lista incluye colaboradres en Argentina Libre entre 1940 y 1943.

8 La lista incluye a los miembros de distintos órganos internos, así como a los miembros y autoridades de las comisiones del Cabildo Abierto, que consistió en una serie de reuniones públicas organizadas por Acción Argentina en mayo de 1941, extraídas de Fitte y Sánchez Zinny (1944: 227-245, 261-268). 


\section{CUADRO 1 (Cont.)}

\begin{tabular}{|c|c|c|}
\hline & Argentina Libre & Acción Argentina \\
\hline $\begin{array}{l}\text { Miembros de } \\
\text { partidos de la } \\
\text { Concordancia }\end{array}$ & $\begin{array}{l}\text { Roberto Giusti, Héctor González } \\
\text { Iramain. }\end{array}$ & $\begin{array}{l}\text { Ramón J. Cárcano, José } \\
\text { María Cantilo, Antonio } \\
\text { Santamarina, Hector } \\
\text { González Iramain, Federico } \\
\text { Pinedo, José A. Cámara, } \\
\text { Carlos Saavedra Lamas, } \\
\text { Reynaldo Pastor, Vicente } \\
\text { Solano Lima, Gilberto } \\
\text { Suárez Lago. }\end{array}$ \\
\hline Sur & $\begin{array}{l}\text { Eduardo González Lanuza, } \\
\text { Ezequiel Martínez Estrada, } \\
\text { Guillermo de Torre. }\end{array}$ & $\begin{array}{l}\text { Victoria Ocampo, Eduardo } \\
\text { Mallea, Silvina Ocampo, } \\
\text { Adolfo Bioy Casares, Jorge } \\
\text { Luis Borges, Norah Borges } \\
\text { de Torre, Oliverio Girondo. }\end{array}$ \\
\hline Nosotros & $\begin{array}{l}\text { Roberto Giusti, Cándido } \\
\text { Villalobos Domínguez, José } \\
\text { María Monner y Sanz, Luis } \\
\text { Emilio Soto. }\end{array}$ & \\
\hline $\begin{array}{l}\text { Orden } \\
\text { Cristiano }\end{array}$ & $\begin{array}{l}\text { Augusto Durelli, Eugenia } \\
\text { Silveyra de Oyuela, Rafael } \\
\text { Pividal. }\end{array}$ & $\begin{array}{l}\text { Alberto Duhau, Rafael } \\
\text { Pividal. }\end{array}$ \\
\hline $\begin{array}{l}\text { Colegio Libre } \\
\text { de Estudios } \\
\text { Superiores }\end{array}$ & $\begin{array}{l}\text { Julio Payró, Jorge Romero Brest, } \\
\text { José Luis Romero, Francisco } \\
\text { Romero, Américo Ghioldi. }\end{array}$ & $\begin{array}{l}\text { Adolfo Bioy, Francisco } \\
\text { Romero, Margarita Arguas. }\end{array}$ \\
\hline $\begin{array}{l}\text { Sociedad } \\
\text { Argentina de } \\
\text { Escritores } \\
\text { (SADE): } \\
\text { autoridades y } \\
\text { miembros del } \\
\text { Consejo } \\
\text { Directivo9 }\end{array}$ & $\begin{array}{l}\text { Alberto Gerchunoff (vocal, 1938- } \\
\text { 1940, vicepresidente, 1940-1942), } \\
\text { Luis Emilio Soto (vocal, 1940- } \\
\text { 1942), Pablo Rojas Paz (vocal, } \\
\text { 1940-1942), José María Monner y } \\
\text { Sanz (vocal, 1938-1940), } \\
\text { Conrado Nalé Roxlo (vocal, } \\
\text { 1938-1940), Roberto Giusti } \\
\text { (presidente, 1934-1938), José } \\
\text { Gabriel (secretario, 1942-1943). }\end{array}$ & \\
\hline
\end{tabular}

9 Boletín de la Sociedad Argentina de Escritores (SADE) (1938: I, 15); (1944: II, 24); (1946: II, 28); SADE (1941). 
De este cuadro se destaca la activa participación de importantes líderes y miembros de los partidos radical, demócrata progresista y socialista -con una destacada presencia de éstos últimos. Estos grupos constituían el núcleo de la oposición política a la Concordancia, basada en la defensa de la tradición liberal democrática del país y el ferviente apoyo a la causa aliada. La presencia de miembros y dirigentes de los grupos de la Concordancia se explica por la posición de abierta defensa de los aliados por parte de sectores conservadores tradicionales. También participaban destacados intelectuales y profesionales agrupados en las revistas literarias Sur y Nosotros, el CLES, la Sociedad Argentina de Escritores (SADE), los liberales católicos agrupados en la revista Orden Cristiano, y se publicaban escritos y colaboraciones de escritores antifascistas extranjeros que incluían a Emil Ludwig, Stefan Zweig, Jules Romains, Jacques Maritain, Harold Lasky, Jacinto Grau, Gaetano Salvemini y Leo Ferrero.

Esta cartografía social e ideológica de los grupos e individuos que colaboraban en Argentina Libre revela que la publicación abarcaba fundamentalmente al arco político e intelectual antifascista que se había definido progresivamente en la segunda mitad de la década del 30 (Nállim 2002). En su primer número, Argentina Libre expresaba con claridad su posición, fundada en la "idea coherente" de "libertad" que había guiado la historia argentina desde la revolución de Mayo y había sido expresada por Mariano Moreno, Bernardino Rivadavia, Esteban Echeverría, Juan B. Alberdi, Bartolomé Mitre y la Constitución Nacional de 1853. Enraizada en esta genealogía liberal, Argentina Libre denunciaba a los "pseudo-argentinos" que apoyaban a Hitler y Stalin y deseaban la implantación de "sistemas políticos que amenazan nuestras instituciones libres". Frente a esta amenaza, explicitaba su programa:

Argentina Libre, escrita por argentinos para los argentinos, tendrá el programa que expresa tal título: luchar por una Argentina libre de influencias extrañas, igual a sí mima, idéntica a su tradición. Carecemos de preocupaciones políticas mezquinas, pero estamos con las democracias porque la democracia es el contenido filosófico de la Constitución Nacional y porque los soldados de Francia y de Inglaterra luchan en defensa de una civilización que representa también nuestro patrimonio espiritual. $^{10}$

La misión de Argentina Libre consistía así en la defensa del liberalismo político y cultural identificado con la esencia histórica del país y con la causa aliada en la Segunda Guerra Mundial. Este liberalismo político y cultural esta- 
ba basado en la defensa de las libertades y derechos políticos y civiles, privados y públicos, y la oposición a movimientos y regímenes autoritarios y totalitarios, locales y extranjeros. Esta definición amplia del liberalismo permitía su defensa por parte de individuos pertenecientes a los diversos grupos que colaboraban en la publicación. Así, Alberto Cortés Plá, decano de la Facultad de Ingeniería de la Universidad de Buenos Aires, llamaba a mantener incólume "nuestra estructura, constitucional, democrática y liberal" tanto en la Universidad como en la sociedad civil. ${ }^{11}$ El historiador y escritor socialista José Luis Romero sostenía que "el escritor americano" existía "por la libertad" y, por lo tanto, debía repudiar "toda coacción a la libertad individual" y "los atentados contra la libertad de su país y de los países americanos". ${ }^{12}$ Más explícitamente, el historiador y político radical Emilio Ravignani proclamaba que "en la Universidad y fuera de ella soy demócrata liberal". ${ }^{13}$

La defensa del liberalismo político y cultural estaba relacionada con las duras críticas que la publicación dirigió a distintos grupos que, en su opinión, cuestionaban el legado liberal argentino o defendían una neutralidad percibida como favorable al Eje, como era el caso de varios círculos nacionalistas. Todos ellos eran englobados como parte de la "quinta columna", aliados locales de Hitler y Mussolini que corrompían el país y lo preparaban para un gobierno totalitario. Argentina Libre atacó específicamente a los intelectuales que defendían el revisionismo histórico, cuya glorificación de Juan Manuel de Rosas y su régimen en el siglo XIX y su crítica a la experiencia histórica liberal argentina eran usadas por algunos grupos nacionalistas neutralistas en el contexto de la Segunda Guerra Mundial. ${ }^{14}$ Desde esta perspectiva, Guillermo Salzar Altamira calificó al revisionismo como una "receta nazi" y "uno de los signos físicos que distinguen a los germanófilos criollos", mientras que Roberto Giusti sostenía que los "exaltadores del Rosismo" eran "nazis criollos" irritados por el proteccionismo comercial británico. ${ }^{15}$

Como parte de su campaña antitotalitaria, Argentina Libre también dedicó sus críticas a la Iglesia Católica argentina, fuertemente influida y movilizada por ideas autoritarias y antiliberales (Zanatta 1997 y 2000). Las denuncias no se limitaban a "los católicos partidarios de Hitler", considerados por Salazar Altamira como "traidores del cristianismo" y "espías y siervos del enemigo",

11 Argentina Libre, 6 de junio de 1940: 5.

12 Argentina Libre, 27 de junio de 1940: 10.

13 Argentina Libre, 21 de agosto de 1941: 2.

14 Sobre el revisionismo histórico se puede consultar Halperin Donghi (1971), Quattrocchi-Woisson (1995), Svampa (1994) y Cattaruzza (1993).

15 Argentina Libre 12 de junio de 1941: 8 y 19 de junio de 1941: 2. Ver, también, 25 de julio de 1940: 1 y 8; 11 de abril de 1940: 2, y 19 de junio de 1941: 1. 
sino también a los líderes de "las masas católicas" que colaboraban en la formación de "activas células antidemocráticas y fascistizantes" evidentes desde el Congreso Eucarístico Internacional de 1934. ${ }^{16}$ Argentina Libre elogiaba, por oposición, a "los católicos liberales y democráticos, que los hay y muy respetables", quienes hallaron acogida en sus páginas. ${ }^{17} \mathrm{Tal}$ fue el caso de Eugenia Silveyra de Oyuela, una de las personas más activas en la revista liberal católica y pro-aliada Orden Cristiano, quien destacaba que la Iglesia no había condenado el liberalismo identificado con "las libertades políticas y sociales encarnadas por los sistemas democráticos que hoy luchan contra el totalitarianismo", sino el "mal uso de la Libertad, que transforma al individuo en un esclavo del mal". ${ }^{18}$

Esta fuerte defensa del liberalismo en lo político y cultural no se tradujo, sin embargo, al ámbito económico. En general, las discusiones económicas no fueron el tema central del semanario, enfocado esencialmente a apoyar a los aliados y a luchar contra el totalitarismo. Salvo algunas expresiones de un liberalismo económico ortodoxo en los primeros números, ${ }^{19}$ predominaban opiniones más matizadas y compatibles con los variados grupos que participaban en sus páginas. En general, se hacía énfasis en el desarrollo de políticas sociales y económicas reformistas que pudieran resolver los problemas creados por la guerra. Además, se precisaba que dichas políticas y la intervención económica del estado sólo podían ser implementadas por regímenes democráticos y respetando libertades y derechos esenciales. ${ }^{20}$ En esta línea, el semanario dio cabida a colaboradores nacionales y extranjeros que denunciaban las políticas económicas de los totalitarismos como material y espiritualmente destructivas. ${ }^{21}$

Desde esta posición, el socialista Carlos Sánchez Viamonte afirmaba que "el individualismo económico morirá" con la guerra porque "estamos en el ciclo de la justicia económica", mientras que el economista Alejandro Shaw sostenía que era necesario "subordinar la política económica a la política social" para evitar las guerras entre los estados y mejorar "el standard de vida de las capas más pobres". ${ }^{22}$ Distintos colaboradores consideraron temas tales como la distribución de tierras, la creación de pequeños propietarios y el refuerzo del federalismo para crear una economía decentralizada y diversifica-

\footnotetext{
16 Argentina Libre, 22 de agosto de 1940: 5; también, 8 de mayo de 1941: 8.

17 Argentina Libre, 20 de noviembre de 1941: 1.

18 Argentina Libre, 14 de enero de 1942: 5.

19 Argentina Libre, 21 de marzo de 1940: 2.

20 Argentina Libre, 1 de agosto de 1940: 1, 5 y 8.

21 Argentina Libre, 18 de julio de 1940: 4 y 8; 5 de diciembre de 1940: 5, y 12 de diciembre de 1940: 6 .

22 Argentina Libre, 18 de julio de 1940: 4 y 10 de octubre de 1940: 1 y 3.
} 
da. ${ }^{23}$ La industria también fue motivo de varios artículos, que señalaron los desequilibrios económicos entre las regiones del país y el progreso industrial que el país había alcanzado. ${ }^{24} \mathrm{~A}$ pesar de estas opiniones, el principal proyecto de industrialización presentado por el gobierno nacional en este periodo, el llamado Plan Pinedo de 1940, fue recibido con una cautelosa crítica, dada la oposición política de radicales y socialistas al plan en el Congreso y la participación de su autor, Federico Pinedo, en instituciones y círculos pro-aliados. ${ }^{25}$

Basada en estas posiciones ideológicas, la vinculación de la lucha contra los grupos antidemocráticos y antiliberales en el país con aquella contra el Eje llevó a Argentina Libre a una posición crítica respecto de la administración de Castillo, exigiendo tanto el fin de prácticas políticas y electorales cuestionables como así también el abandono de la neutralidad percibida como favorable a Alemania. Argentina Libre siguió con atención la situación nacional e internacional en sus primeros meses de existencia. Expresó su entusiasmo y apoyo a Ortiz por su política de regeneración institucional, reflejada en las intervenciones de Buenos Aires y Catamarca, y por haber adoptado inicialmente la posición de no beligerancia en la Segunda Guerra Mundial. Estas decisiones representaban, en su opinión, la esperanza de intensificar la "desinfección del territorio argentino contra los efectos de la propaganda nazi" y "sus métodos de penetración y conquista pacífica" ${ }^{26} \mathrm{Al}$ mismo tiempo, Argentina Libre informaba detalladamente sobre los avances nazis en Europa occidental. El semanario presentó la caída de París, "el baluarte moral de la civilización", en junio de 1940 como una tragedia y una advertencia sobre las "negras amenazas" que se cernían sobre América, advirtiendo que el enemigo "ya está entre nosotros". La caída de París también significaba que la neutralidad ya no era posible porque la guerra era un "problema moral" entre el bien y el mal que requería que la Argentina cumpliera con los tratados inter-americanos de solidaridad. ${ }^{27}$

23 Argentina Libre, 10 de octubre de 1940: 4 y 8; 30 de octubre de 1940: 2, y 7 de noviembre de 1940: 1 y 2.

24 Argentina Libre, 14 de marzo de 1940: 3 y 5 de septiembre de 1940: 4.

25 Por ejemplo, Argentina Libre publicó luego una de las conferencias de Pinedo en Acción Argentina defendiendo la necesidad de mantener e intensificar el comercio con Inglaterra y el resto de los países americanos (2 de julio de 1942: 4 y 8). Significativamente, el único comentario sobre el plan consistió en una entrevista a Alvear, en la cual se manifestó su oposición y la del radicalismo al plan en términos mucho más amistosos que la posición oficial del partido en el Congreso Nacional. (Argentina Libre, 20 de diciembre de 1940: 1 y 10). Sobre la posición oficial del radicalismo y la de sus dirigentes sobre el plan Pinedo, ver la revista radical Hechos e Ideas. Revista Radical (1941: VI, X, 38-39). Argentina Libre, 7 de marzo de 1940: 1; 14 de marzo de 1940: 3, y 16 de mayo de 1940: 2.

27 Argentina Libre, 20 de junio de 1940: 3; 8 de agosto de 1940: 1 y 8, y 7 de noviembre de 1940: 10. 
Argentina Libre expresó su preocupación por la crisis política desatada por el programa electoral de Ortiz y por su forzada delegación del poder presidencial en Castillo. ${ }^{28}$ La preocupación se transformó en abierta crítica una vez que Castillo asumió la conducción del gobierno, permitiendo el retorno del fraude electoral y la reafirmación de una política exterior neutral. Aludiendo al fraude en Santa Fe y Mendoza en diciembre de 1940 y enero de 1941, el radical Honorio Pueyrredón sostuvo en Argentina Libre que significaba "una nueva regresión a lo pasado y una amenaza a lo porvenir", mientras que el demócrata progresista Juan José Díaz Arana argumentaba que el fraude no sólo atacaba la democracia sino que estaba directamente relacionado con los totalitarismos, porque "la dictadura suprime el sufragio". ${ }^{29}$

En este contexto, Argentina Libre cubrió el intento y el fracaso de la tregua política entre el gobierno y la oposición radical emprendido por Federico Pinedo a través de sus conversaciones con Alvear. El semanario culpó del fracaso al gobierno de Castillo y aplaudió a aquellos conservadores que a continuación abandonaron el gobierno, como fue el caso de Julio A. Roca. ${ }^{30}$ Sin embargo, también argumentó que este fracaso era el resultado de un problema más profundo relacionado con la cultura política argentina, y atribuyó el fracaso de tregua política "nuestra falta de educación política", especialmente por parte de conservadores y radicales. ${ }^{31}$ En este sentido, señalaba que si bien el país era esencialmente una democracia, en la práctica estaba lejos de serlo porque:

No hemos concretado en un siglo y tres décadas de ejercicio sobresaltado de las instituciones una ética republicana, una concepción del papel de los organismos que expresan a la muchedumbre, ni comprendemos que la política no es una industria sino una misión. ${ }^{32}$

A partir de enero de 1941, la oposición de Argentina Libre a Castillo creció en vehemencia. A través de artículos de políticos de distintos partidos -incluyendo conservadores- atacó la política de neutralidad sosteniendo que era imposible de sostener y defender e implicaba ser indiferente o abiertamente fascista. ${ }^{33}$ En el orden interno, le otorgó amplia cobertura a una serie de actos públicos organizados en mayo de 1941 por Acción Argentina, el llamado

28 Argentina Libre, 8 de agosto de 1940: 3 y 29 de agosto de 1940: 3.

29 Argentina Libre, 2 de enero de 1941: 1 y 10. También, 9 de enero de 1941: 1 y 10.

30 Argentina Libre, 30 de enero de 1941: 3.

31 Argentina Libre, 16 de enero de 1941: 3.

32 Argentina Libre, 9 de enero de 1941: 3.

33 Argentina Libre, 24 de febrero de 1941: 1 y 10; 10 de abril de 1941: 1 y 10; 3 de abril de 1941: 1, y1 de mayo de 1941: 1. 
"Cabildo Abierto", en defensa de los valores democráticos del país. ${ }^{34}$ También prestó atención detallada a las actividades de la Comisión de Investigación de las Actividades Anti-argentinas de la Cámara de Diputados del Congreso, iniciada e impulsada por radicales y socialistas. En este último caso, Argentina Libre criticó que "el Poder Ejecutivo no combate al nazismo interno con la energía conveniente y tampoco permite que lo combatan y denuncien los que representan la soberanía popular y, por lo tanto, el régimen democrático". ${ }^{35} \mathrm{La}$ oposición a Castillo alcanzó tal vehemencia que Argentina Libre publicó una entrevista altamente amistosa y favorable al ex-presidente Justo, a quien radicales, socialistas y demócratas progresistas habían atacado en la década anterior por su gobierno fraudulento y que ahora era considerado un oportuno aliado, por su oposición a Castillo y su postura aliadófila. ${ }^{36}$

Cuando el ataque japonés a Pearl Harbour en diciembre de 1941 desató la intervención estadounidense en la guerra, Argentina Libre lanzó un ardiente llamado al gobierno a unirse a Estados Unidos y los aliados "en la defensa del suelo continental, en riesgo de transformarse en tierra japonesa o en tierra teutónica", basada en la unidad de América formada por "designios hereditarios", "hábitos y formas de sensibilidad" y la "convergencia de intereses recíprocos". ${ }^{37}$ Otro editorial urgía al gobierno a cumplir con los pactos de cooperación y solidaridad interamericanos y a terminar con la política gubernamental de "forzada neutralidad con Gran Bretaña". ${ }^{38}$ En los siguientes meses de 1942, el semanario renovó el llamado a la solidaridad continental expresada en la conferencia interamericana de Río de Janeiro y aplaudió la decisión de México y Brasil de sumarse a los aliados, presentándolos como ejemplos que el gobierno argentino debería imitar. ${ }^{39}$

Es necesario recordar que la interpretación binaria de Argentina Libre-que identificaba al gobierno con el fraude y la neutralidad favorable a los regíme-

34 Argentina Libre, 22 de mayo de 1941: 1, y 29 de mayo de 1941: 1 y 29.

35 Argentina Libre, 17 de julio de 1941: 3. Desde 1940 Argentina Libre había denunciado lo que consideraba ataques a las libertades públicas e individuales, tales como el proyecto de ley sobre la defense del orden público, considerado como una restricción a la libertad de expresión (13 de junio de 1940: 3). También denunció la suspensión y proceso administrativo contra José Gabriel, escritor, profesor, y frecuente colaborador del semanario, por criticar al gobierno de Buenos Aires, lo que constituía un ejemplo de censura y de lo que podrían hacer Alemania y los germanófilos y nazis locales en caso de triunfar, Argentina Libre, 24 de abril de 1941: 1 y 10. Argentina Libre, 26 de junio de 1941: 1.

37 Argentina Libre, 11 de diciembre de 1941: 1-3.

38 Argentina Libre, 11 de diciembre de 1941: 3.

39 Argentina Libre, 15 de enero de 1942: 1-2; 4 de junio de 1942: 1y 3, y 3 de septiembre de 1942. 
nes totalitarios y la contrastaba con la oposición política, supuestamente liberal y democrática y que apoyaba a los aliados- es una construcción simplista, nacida al calor del conflicto político y que esconde una realidad mucho más compleja. Castillo no era pro-nazi, y su neutralidad tenía más bien que ver con la tradición histórica de la Argentina en materia de política exterior y su opinión negativa sobres los Estados Unidos. Por otra parte, los grupos nacionalistas durante estos años se encontraban divididos (Navarro Gerassi 1969: 147158, Buchrucker 1987: 184-258, Rock 1993: 138-144), los nacionalistas pro-Eje parecen no haber influido en la política exterior de Castillo, y figuras nacionalistas de envergadura criticaron abiertamente sus políticas domésticas (Senkman 1995: 36, Scenna 1984: 275-283, 245-258, Buchrucker 1987: 258276). Los grupos pro-aliados, y entre ellos, Argentina Libre, intencionalmente borraron todas estas diferencias y sutilezas en su lucha contra el gobierno, y usaron también la bandera anti-totalitaria y pro-democrática para encubrir sus propias divisiones y tensiones frente al conflicto mundial y el gobierno (Senkman 1995: 24-35, Ruiz Jiménez 1994: 183, Newton 1995). En el caso de Argentina Libre, se pueden observar algunos ejemplos de estas tensiones internas. Por ejemplo, un editorial atribuyó la derrota radical en las elecciones de Buenos Aires de marzo de 1942 a sus "rencillas internas [...], sus vacilaciones pueriles, a sus debates sofocados" ${ }^{40}$ Otros artículos, que denotan una clara influencia socialista, observaban que radicales y conservadores compartían una retórica política e ideológica anticuada y vacía y prácticas corruptas. ${ }^{41}$

La oposición de Argentina Libre a la política exterior de Castillo no sólo tendió a borrar esas tensiones de la superficie sino que también se reflejó en la creciente crítica a su gobierno, lo que finalmente provocó la decisión oficial de suspender temporalmente la publicación. Cuando el gobierno decidió después de Pearl Harbour imponer el estado de sitio con el pretexto de impedir la difusión de información tendenciosa o alarmista, Argentina Libre señaló cautelosamente que esa medida implicaba una restricción de la libertad de expresión. ${ }^{42}$ En febrero/marzo de 1942, la frontal oposición a Castillo le valió una suspensión por dos semanas. Argentina Libre atribuyó esta medida a un deplorable "malentendido", en el sentido de que el estado de sitio era un instrumento legal que debería ser aplicado contra "los antidemócratas y las quinta columnas". ${ }^{43}$ Lejos de solucionarse, el conflicto con el gobierno se agravó cuando en julio de 1942 el semanario publicó una dura crítica a la clausura del

\footnotetext{
40 Argentina Libre, 12 de marzo de 1942: 3.

41 Argentina Libre, 5 de marzo de 1942: 3, y 12 de marzo de 1942: 3.

42 Argentina Libre, 25 de diciembre de 1941: 3.

43 Argentina Libre, 5 de marzo de 1942: 3.
} 
Concejo Deliberante de Buenos Aires, que Castillo había adoptado en octubre de 1941. Argentina Libre calificó la medida como "un golpe de estado", una concesión a "a los elementos reaccionarios y filofascistas de diverso tono que suelen rodear a los hombres del Poder Ejecutivo", y "un ensayo, en formato reducido, de gobierno corporativo". 44

Este artículo, junto con otros publicados en el número del 30 de julio, provocó una nueva suspensión de la publicación. A pesar de protestar la decisión como infundada, ${ }^{45}$ el mismo número incluía una colaboración de Díaz Arana llamando a luchar "contra todos los recursos de los oficialismos fraudulentos opresores" y una nota felicitando al Brasil por unirse a los aliados en la guerra. Ante esta posición, el gobierno nuevamente impuso una suspensión más larga durante los meses de septiembre y octubre. Al reiniciar su publicación, Argentina Libre se defendió sosteniendo, con tono de fingida inocencia, que "nunca hemos combatido al gobierno; nunca hemos agraviado ni censurado a los funcionarios que lo ejercen". Por el contrario, la crítica ante algunos actos que resultaban "balbucientes, desmayados o poco enérgicos" estaba impulsada por deseo vehemente de "colaborar con la mayor eficacia en la defensa de la libertad, independencia y democracia de América". ${ }^{46}$

En este contexto, a mediados de 1942 Argentina Libre comenzó a defender el proyecto de la Unión Democrática, una alianza de partidos políticos y sectores sociales liberales y democráticos para luchar por la democracia y la libertad en el orden nacional e internacional. Esta alianza había sido oficialmente propuesta por el Partido Socialista en diciembre de 1941, y fue acogida rápida y entusiastamente por Acción Argentina, en dónde Nicolás Repetto ya había mencionado la idea con anterioridad. (Fitte y Sánchez Zinny 1944: 391-405, García 1995: 72-76). La Unión Democrática no era una empresa fácil, debido a las diferencias y conflictos entre las autodenominadas fuerzas democráticas y liberales que se reflejaban ocasionalmente en Argentina Libre, como ya se ha mencionado. Sin embargo, a medida que Argentina Libre intensificaba su oposición a Castillo, estas diferencias desparecieron y el semanario se convirtió en el vocero de la Unión Democrática para las elecciones presidenciales de 1943.

El primero en lanzar esta idea en el semanario fue el demócrata progresistas Díaz Arana, quien llamó a la "unión de las fuerzas liberales" en un programa que incluía "en el orden internacional, la efectiva solidaridad con los países que luchan contra el nazifascismo y el cumplimiento de los pactos y convenciones panamericanos, y en el orden interno, el restablecimiento del

44 Argentina Libre, 23 de julio de 1942, p. 1.
45 Argentina Libre, 3 de septiembre de 1942: 3.
46 Argentina Libre, 5 de noviembre de 1942: 1. 
régimen institucional" ${ }^{47}$ En la misma línea, Argentina Libre manifestó su apoyo a la declaración oficial del Partido Socialista sobre la Unión Democrática de octubre de $1942,{ }^{48}$ dio lugar en sus páginas y apoyó a los grupos radicales alvearistas que propulsaban la idea y combatió a los radicales intransigentes que se resistían a aceptarla. ${ }^{49}$ Asimismo, el semanario lamentó la muerte de Alvear en marzo de 1942, Ortiz en julio de 1942, y Justo en enero de 1943, por ser las figuras políticas que podrían haber forjado esa alianza. En el caso de Justo, esto implicó su rehabilitación definitiva por los sectores que lo habían atacado en la década anterior, basada en que, según la publicación, hacia 1943 "estaba lejos" de posiciones anteriores y apoyaba los "métodos democráticos" y la "libertad del individuo". 50

De esta manera, hacia 1943 los grupos intelectuales y políticos opositores al gobierno de Castillo confluían en la idea de formar la Unión Democrática. En este proceso, Argentina Libre jugó un rol importante en la conformación de esta alianza democrática y antitotalitiaria, al consolidar los vínculos políticos e ideológicos entre estos grupos e individuos desde 1940.

\section{Del antifascismo al antiperonismo: el régimen militar de 1943, Argentina Libre y ...Antinazi, 1943-1946}

La crisis política del país -y con ella, la limitada restauración democrática iniciada en 1932- concluyó con el golpe militar del 4 de junio de 1943. Argentina Libre, representando la opinión de los sectores que colaboraban en sus páginas, inicialmente celebró el golpe y manifestó sus altas expectativas sobre el futuro político del país. A través de distintos artículos, el semanario argumentó que con el golpe "el país se reincorpora a la historia" porque "estaba como secuestrado por sus mandatarios", "estábamos viviendo en plena dictadura" e "íbamos hacia la guerra civil". ${ }^{51}$ Los demócrata progresistas Honorio Roigt y Juan José Díaz Arana explicaron que el éxito del golpe había sido posible por la oposición popular al "imperio de la fuerza y del fraude" impuesto por Castillo, y negaban que la "revolución" hubiera sucedido, "como algunos grupos minoritarios la querían, para reformar un sistema constitucional" o para "reforzar las

\footnotetext{
47 Argentina Libre, 3 de septiembre de 1942: 2.

48 Argentina Libre, 5 de noviembre de 1942: 3.

49 Argentina Libre, 14 de enero de 1943: 1; 21 de enero de 1943: 3, y 28 de enero de 1943: 1.

50 Argentina Libre, 26 de marzo de 1942: 1 y 9; 16 de julio de 1942: 3, y 14 de enero de 1943: 1,3 y 7.

51 Argentina Libre, 10 de junio de 1943: 1.
} 
tendencias totalitarias o nazifascistas, gratas al gobierno depuesto".52 Por su parte, el radical Mario Guido y el socialista Juan Antonio Solari sostenían que todos los sectores políticos y sociales deberían colaborar con el nuevo gobierno, al cuál le indicaban el nuevo camino a seguir, que incluía la remoción de situaciones de "inmoralidad institucional" y la continuación de la investigación y represión de los grupos antidemocráticos y totalitarios. ${ }^{53}$

Estas expectativas iniciales fueron rápida y brutalmente desmentidas por el gobierno militar, que confirmó los temores inicialmente expresados por José Gabriel en Argentina Libre sobre la presencia de grupos e individuos "contrarrevolucionarios" y "nazifascistas" en el gobierno. ${ }^{54}$ El 15 de julio el gobierno decretó la clausura de Argentina Libre y Acción Argentina con el pretexto de ser organizaciones comunistas. La institución cultural dirigida por los comunistas, la AIAPE, también fue clausurada, e intelectuales y políticos de esa filiación, tales como Benito Marianetti y Héctor Agosti, fueron encarcelados (Nállim 2003: 132-134). Reconocidos intelectuales nacionalistas y de derecha tales como Gustavo Martínez Zuviría, Carlos Obligado, Leopoldo Marechal, Jordán Bruno Genta y Alberto Baldrich, se incorporaron a distintas reparticiones gubernamentales en el orden nacional y provincial. Al mismo tiempo que se mantenía la neutralidad argentina en el conflicto mundial, el gobierno creó en octubre la Secretaría de Prensa e Información, que impuso una severa censura en todo el país.

Intelectuales y políticos que habían colaborado en Argentina Libre y Acción Argentina dieron a conocer un manifiesto en los principales diarios de Buenos Aires el 15 de octubre exigiendo "democracia efectiva y solidaridad americana". ${ }^{55}$ El gobierno reaccionó despidiendo de sus cargos en la administración pública a quiénes lo habían firmado, medida que afectó, entre otros, a Giusti, Díaz Arana, Juan Valmaggia, Adolfo Lanús, Adolfo Bioy, José Antelo, Julio Payró, Alejandro Ceballos, José Peco, Santiago Fassi, Américo Ghioldi y Bernardo Houssay. ${ }^{56}$ Las universidades públicas también fueron objeto de despidos masivos bajo la influencia de interventores nacionalistas, y en diciembre el gobierno militar coronó su giro autoritario y antiliberal con dos decretos que abolían los partidos políticos e imponían la enseñanza católica obligatoria en las escuelas.

52 Argentina Libre, 24 de junio de 1943: 1, y 1 de julio de 1943: 1 y 7.

53 Argentina Libre, 17 de junio de 1943: 1, 3 y 7; 24 de junio de 1943: 1-2, y 8 de julio de 1943: 3 .

54 Argentina Libre, 24 de junio de 1943: 3, y 1 de julio de 1943: 3-4.

55 La Prensa, 15 de octubre de 1943: 6.

56 La Vanguardia, 21 de octubre de 1943: 1, 23 de octubre de 1943: 3, y La Prensa, 21 de octubre de 1943: 8 . 
De esta manera, el régimen militar se transformaba en la peor pesadilla de los grupos intelectuales y políticos que habían colaborado en Argentina Libre: la instalación de un régimen abiertamente antidemocrático y antiliberal influido por grupos nacionalistas y derechistas, que reprimía a los sectores liberales y democráticos y mantenía la neutralidad argentina en la guerra. Esta percepción es de una importancia fundamental, porque se convirtió en el lente a través del cuál los grupos auto-proclamados liberales y democráticos interpretaron el surgimiento de Perón y su movimiento. Esta interpretación ciertamente simplificaba las tensiones y disputas internas en el gobierno militar, los cambios que sufrió a lo largo de su existencia entre 1943 y 1946, y los motivos profundos del fenómeno peronista (Potash 1982: 341-401, Rouquié 1982: 9-72, Torre 1990, Halperin Donghi 2000: 135-155). Sin embargo, para aquellos grupos no cabían dudas de que Perón encarnaba posiciones ideológicas totalitarias. Perón había participado en la logia que había llevado a cabo el golpe, y hacia julio de 1944 ocupaba los cargos de Secretario de Trabajo y Previsión, Ministro de Guerra, y Vicepresidente.

La liberación de París en agosto de 1944 renovó las energías de los grupos liberales y democráticos en su lucha contra el totalitarismo en el exterior y en el país, lo que se puede percibir en las actas y declaraciones de la SADE, las páginas de Sur y Orden Cristiano, y la cobertura periodística de La Nación y La Prensa a las manifestaciones públicas en apoyo de la Francia libre (Nállim 2002: 206). Un intento fallido de relanzar Argentina Libre alcanzó a publicar cinco números entre diciembre de 1944 y enero de 1945 antes de que el gobierno clausurara la publicación nuevamente. Sin embargo, para entonces la evidente cercanía de la derrota del Eje en la guerra había incrementado la organización e intensidad de la oposición política e intelectual al régimen militar.

En este contexto, ...Antinazi publicó su primer número el 22 de febrero de 1945. Los puntos suspensivos aludían a la palabra "Argentina", cuyo uso le fue vedado por el gobierno. Salvo el nombre, la publicación mantuvo básicamente el mismo formato y los colaboradores que habían participado anteriormente en Argentina Libre. La lista de colaboradores incluía radicales, demócrata progresistas, socialistas, conservadores, antiguos antipersonalistas y socialistas independientes y comunistas. Asimismo, también incluía a algunos dirigentes de la difunta Acción Argentina -E. F. Sánchez Zinny, Rodolfo Fitte, Alejandro Ceballos- e intelectuales relacionados con el CLES -Noble, Valmaggia, Díaz Arana, Giusti, Ghioldi-y Orden Cristiano -Manuel Ordóñez, Eugenia Silveyra de Oyuela. Finalmente, el nuevo semanario publicaba ensayos de colaboradores extranjeros tales como Max Lerner, George Reed, y Ettore Rossi provistos por la agencia de noticias ONA. ${ }^{57}$ 
De esta manera, ...Antinazi reunía nuevamente al amplio espectro político e intelectual que había encontrado un primer espacio común en Argentina Libre. En el politizado clima de 1945,...Antinazi expresó una posición ideológica y política más endurecida frente a la coyuntura nacional e internacional, proponiéndose como un punto de encuentro para todos aquellos que se identificaran como "antinazis", porque el nazismo "es la anticivilización, la negación de la libertad y por ende de la cultura". ${ }^{58}$ Tal como había sucedido con Argentina Libre, ...Antinazi vinculó la situación internacional con la nacional, apoyando a los aliados y exigiendo el retorno a un gobierno constitucional. En los meses de marzo y abril de 1945, exigió que el gobierno declarara la guerra a Alemania y cumpliera con los tratados internacionales de Chapultepec y San Francisco, que requerían la existencia de gobiernos democráticos y representaban el triunfo de "las ideas liberales en que se funda la autonomía del individuo, el ejercicio de derechos fundamentales, su aspiración a la felicidad socialmente asequible". ${ }^{5}$ El semanario celebró la declaración de guerra a Alemania a fines de marzo, criticando que su demora se había debido al "nacionalismo intransigente" del gobierno, ${ }^{60}$ y la caída de Berlín en mayo, enfatizando que la Argentina ahora invitada a sumarse a las deliberaciones de San Francisco era la Argentina "de Rivadavia, Sarmiento, Mitre, Sáenz Peña”, quienes representaban la tradición repudiada por "la revolución nacionalista [...] desde el gobierno". ${ }^{61}$

En esta línea, ...Antinazi vinculó directamente al régimen militar con los totalitarismos derrotados. Dado que el régimen consistía en "una simiesca y trasnochada imitación del nazismo", ${ }^{62}$ la misión de ...Antinazi no finalizaría hasta que una derrota similar se produjera en el país. Diversos colaboradores señalaron que el nazismo era "una enfermedad social que puede extenderse como una epidemia mortal" y exigía una lucha permanente, ya que "el virus nacionalista" podía florecer dondequiera que "estos ejemplares" encontraran condiciones favorables. ${ }^{63}$ La infiltración nazi era "vasta y profunda", y según Gerchunoff, la difusión del "hitlerismo y el nazismo" en la Argentina tenían su origen en el impacto de la Guerra Civil Española. ${ }^{64}$

La denuncia del nazismo y del régimen militar fue también acompañada por la renovada y violenta crítica a los grupos políticos y culturales nacionalis-

\footnotetext{
58 ...Antinazi, 22 de febrero de 1945: 3.

59 ...Antinazi, 1 de marzo de 1945: 3, 8 de marzo de 1945: 1 y 7, y 15 de marzo de 1945: 3 y 5 .

60 ...Antinazi, 29 de marzo de 1945: 1.

61 ...Antinazi, 3 de mayo de 1945: 1.

62 ...Antinazi, 29 de marzo de 1945: 1-2.

63 ...Antinazi, 1 de marzo de 1945: 3 y 3 de mayo de 1945: 2.

64 ...Antinazi, 15 de marzo de 1945: 1 y 1 de marzo de 1945: 1.
} 
tas, de derecha y vinculados a la Iglesia que se habían relacionado con el gobierno militar, sobre la base de los argumentos que Argentina Libre había ensayado anteriormente. En este sentido, la defensa de la tradición liberal estaba ligada nuevamente a la crítica al revisionismo histórico, ahora presentado como "una tumefacta filosofía de la historia" destinada a demostrar que Rosas era el antecedente del "hitlerismo, el fascismo, el nazismo, lo que es siniestro o pavoroso". ${ }^{65}$ La crítica se extendió a los sectores nacionalistas católicos a través de la columna "Comentarios de un Fraile", en la que se denunciaba la formación de "sacerdotes antidemocráticos" que apoyaban "totalitarismos, la Gestapo, la Inquisición", en contra de Estados Unidos e Inglaterra. ${ }^{66} \mathrm{Al}$ mismo tiempo, el semanario le daba cabida a los grupos liberales católicos que habían apoyado la causa aliada, representado por los escritores vinculados a Orden Cristiano tales como Silveyra de Oyuela, Augusto Durelli, y Manuel Ordóñez.

Alentado por la derrota de Alemania, ...Antinazi redobló sus demandas de elecciones limpias que condujeran al país al régimen constitucional y democrático ${ }^{67}$ al tiempo que denunciaba como totalitaria o fascista toda acción por parte del gobierno que no estuviera dirigida a ese fin. En junio de 1945, la publicación criticó el Estatuto de los Partidos Políticos anunciado por el gobierno como "una nueva manifestación de la tendencia totalitaria" del gobierno con la cuál "va a adquirir los medios legales para influir en la vida de los partidos". ${ }^{68}$ Cuando el gobierno anunció en julio su intención de llamar a elecciones, publicó un programa que incluía el levantamiento del estado de sitio, el fin de la represión y censura oficial, la dimisión del gobierno y la transferencia temporaria del poder a la Suprema Corte. ${ }^{69}$

...Antinazi extendió la crítica del supuesto totalitarismo del gobierno al área económica, sosteniendo que la democracia política necesariamente implicaba el respeto por la libertad económica. Sobre esta base, censuró al gobierno por sus políticas económicas y sociales, percibidas como una dañina y excesiva intervención del estado en la economía vinculada a una demagogia de corte fascista. Distintos colaboradores notaron que esta situación era el resultado del proceso de intervención del estado en la economía iniciado la década anterior, atacaba la libertad y demás "derechos esenciales" y representaba un "dirigismo" de "corte totalitario" similar al derrotado en Europa ${ }^{70}$ Desde esta posi-

\footnotetext{
65 ...Antinazi, 5 de abril de 1945: 1 y 1 de marzo de 1945: 5 .

66 ...Antinazi, 15 de marzo de 1945: 5 y 12 de abril de 1945: 5 .

67 ...Antinazi, 29 de marzo de 1945: 3, 22 de febrero de 1945: 1-2, 1 de marzo de 1945: 7, y 8 de marzo de 1945: 3 y 7 .

68 ...Antinazi, 7 de junio de 1945: 1-2.

69 ...Antinazi, 2 de agosto de 1945: 3 .

70 ...Antinazi, 3 de mayo de 1945, 4 y 6 de junio de 1945: 2 .
} 
ción, Perón se convirtió en el evidente objeto de las acerbas críticas del semanario. En marzo ...Antinazi aludió por primera vez a "un miembro del gobierno" quien "se afana en halagar y servir sin medida a las masas", lo cuál era un ejemplo de "demagogos" que usan el poder "para excitar las pasiones de la numerosa gente humilde". ${ }^{71}$ La política social llevada a cabo por Perón consistía en aumentos salariales basados en préstamos y emisiones de títulos que sólo provocarían inflación y el deterioro económico de toda la población. ${ }^{72}$

De esta manera, ...Antinazi interpretó las políticas económicas y sociales del gobierno y Perón como una manipulación totalitaria por el estado. La publicación apoyó el Manifiesto de la Fuerzas Vivas, anunciado el 16 de junio por las más importantes organizaciones económicas del país en contra de la política social del gobierno que, según el documento, atacaba "la libertad de acción en el área económica" ${ }^{73}$ Esta posición fue seguida de un artículo sobre Getulio Vargas que aludía implícitamente a Perón, denunciando el "principio nazi del capitalismo dirigido" como un "extraordinario instrumento" para halagar "al pueblo trabajador con la ilusión de la equidad y la aparente opresión de su enemigo histórico" al mismo tiempo que se ataca y "somete a obediencia [...] al capitalista, al miembro del consorcio, al gran propietario, al gran industrial, el dueño de la empresa creadora de riqueza". ${ }^{74}$

La crítica a Perón era complementada con aquella dirigida a los grupos obreros que lo apoyaban. Cuando algunos sindicatos manifestaron su crítica al Manifiesto y su apoyo a Perón, fueron denunciados como una "turbamulta", "obsecuentes" obligados a publicar su apoyo para recibir "una precaria protección del Benefactor Máximo" y que representaban "una "minúscula y despreciable excepción en el campo proletario, donde siempre florecieron los más nobles sentimientos de libertad". ${ }^{75}$...Antinazi fue todavía más duro en su evaluación de la importante manifestación llevada a cabo por los sindicatos favorables a Perón el 12 de julio, en defensa de las conquistas sociales que él les había garantizado. De acuerdo a distintos colaboradores, la manifestación consistió en la movilización de "sindicatos oficiales" por "la burocracia nacional y municipal". Los obreros debían recordar "la lección de Italia", en donde las realizaciones de Mussolini resultaron "tan sólo propaganda, simulacro, apariencia". ${ }^{76}$ Silveyra de Oyuela sostuvo que el acto representaba lisa y llanamente la presencia de "Hitler en Argentina" y era "el primer ensayo de propa-

\footnotetext{
71 ...Antinazi, 22 de marzo de 1945: 1.

72 ...Antinazi, 5 de julio de 1945: 1-3.

73 ...Antinazi, 28 de junio de 1945: 1.

74 ...Antinazi, 28 de junio de 1945: 1-3.

75 ...Antinazi, 28 de junio de 1945: 3 y 5 de julio de 1945: 3 .

76 ...Antinazi, 19 de julio de 1945: 1- 3 .
} 
ganda electoral nazista", caracterizado por "voces de violencia", "incitaciones al odio formal" y "lujuria populachera". ${ }^{77}$ Por su parte, Gerchunoff reflexionaba que el acto demostraba que Perón, Mussolini y Rosas representaban el mismo tipo de dictador demagógico. ${ }^{78}$

En este contexto, ...Antinazi se convirtió una vez más en el vocero para la formación de la Unión Democrática contra Perón, lo que era una consecuencia lógica dada la historia previa de Argentina Libre. Alejandro Ceballos y Rodolfo Fitte, líderes de la difunta Acción Argentina, fueron los primeros en avanzar la idea en la publicación a principios de agosto, y a partir de entonces se convirtió en un tema recurrente en sus páginas. ${ }^{79}$ Coherente con este proyecto, ...Antinazi apoyó vehementemente a aquellos grupos dentro de los partidos políticos que se pronunciaron por la Unión Democrática, como fue el caso de los conservadores a través de sendos artículos de Vicente Solano Lima y Rodolfo Moreno que desde marzo habían reclamado por la reorganización conservadora y su colaboración con las fuerzas democráticas. ${ }^{80}$

Con respecto al radicalismo, ...Antinazi criticó duramente a los sectores intransigentes que cuestionaban a la dirigencia alvearista y se oponían a la alianza con las otras fuerzas políticas. El radical Carlos Gallego Moyano y el demócrata progresista Horacio Thedy denunciaron la intransigencia radical como "aislacionismo" y "colaboracionismo" con el gobierno, al tiempo que la publicación denunciaba las conversaciones de algunos radicales con el gobierno. ${ }^{81}$...Antinazi censuró severamente a aquellos dirigentes radicales que, como Hortensio Quijano, se integraron en el gobierno, mientras que censuraba al líder intransigente Amadeo Sabattini por sus negociaciones con Perón. ${ }^{82}$ Alvaro Martínez atribuyó la oposición intransigente a la Unión Democrática a "la infiltración nazi", representada por "virus" tales como "FORJA" en el radicalismo y "nacionalismo" en los conservadores, "verdaderas puntas de lanza de común origen en la Quinta Columna dentro de esos partidos". 83

La aguda polarización política y social del país y el embanderamiento de ...Antinazi en el campo del antiperonismo militante se puede apreciar con plenitud en la cobertura de los cruciales eventos de septiembre y octubre de 1945.

\footnotetext{
77 ...Antinazi, 19 de julio de 1945: 5.

78 ...Antinazi, 19 de julio de 1945: 2.

79 ...Antinazi, 2 de agosto de 1945: 2 y 5 .

80 ...Antinazi, 22 de marzo de 1945: 3, 19 de abril de 1945: 4, 7 de junio de 1945: 6 y 2 de agosto de 1945: 4.

81 ...Antinazi, 3 de mayo de 1945: 2 y 4, y 5 de julio de 1945: 5 .

82 ...Antinazi, 30 de agosto de 1945: 1, 6 de septiembre de 1945: 3 y 5, 20 de septiembre de 1945: 3 .

83 ...Antinazi, 20 de septiembre de 1945: 4.
} 
El semanario le dedicó numeroso espacio a la masiva "Marcha de la Constitución y la Libertad" organizada por la oposición a Perón y que recorrió las calles de Buenos Aires el 19 de septiembre. Exultante, ...Antinazi sostuvo que la manifestación había sido un "día glorioso en las luchas cívicas por la libertad", en el que "el Pueblo con mayúsculas" desfiló como "un ejército sin armas" asumiendo "la representación de la República" y manifestando "su inapelable, definitivo repudio del régimen". ${ }^{84} \mathrm{El}$ semanario siguió con optimismo la crisis interna del régimen militar que culminó el 8 de octubre con la renuncia y prisión de Perón, celebrando la "caída vertical del dictador" como el "triunfo de la libre y democrática conciencia de la ciudadanía argentina". ${ }^{85}$

La alegría y el optimismo no duraron mucho, y contrastan agudamente con las expresiones de malestar, sorpresa y furia con las que ...Antinazi recibió los eventos del 17 de octubre, cuando las masas trabajadoras reunidas en la Plaza de Mayo devolvieron a un Perón triunfante al gobierno. Las descripciones del 17 de octubre que aparecieron en ...Antinazi muestran el grado de violencia y polarización que el conflicto político había alcanzado y las interpretaciones negativas, racistas y clasistas usadas por la auto-denominada oposición liberal democrática para caracterizar a Perón y sus seguidores. Alfredo Palacios y Alejandro Ceballos describieron a los trabajadores de la Plaza de Mayo como un "lumpen proletariat proclive a la violencia" que profería "el grito absurdo, aberrante de odio a la cultura, al libro...y de exaltación a la alpargata". Se trataba de "una muchedumbre heterogénea y bulliciosa, indisciplinada", que no expresó:

Un concepto político nuevo, una aspiración superior o un principio por el cual valiera la pena combatir [...] Todo era incongruente, con gritos personalistas e imposiciones. Parecía como si volviéramos a las fechas pasadas de las hordas del tiempo de Rosas. ${ }^{86}$

Por su parte, el socialista Juan Antonio Solari sostuvo que "elementos reclutados" habían desfilado "en forma turbulenta y provocativa, vitoreando al ex secretario de Trabajo y Previsión" y "cometiendo todo tipo de tropelías", "ensuciando con el nombre del referido funcionario las calles, edificios, medios de transporte. Tales manifestaciones de acentuado carácter populachero y contornos de candombe epilogaron su paso por la capital". ${ }^{87}$ Otro colaborador anónimo describió sombríamente a los manifestantes como “30.000 a 
40.000 personas descamisadas y sudorosas" traídas de fuera de la ciudad que se sumaron a "2.000 o 3.000 hombres de igual laya, vagando en patotas ululantes por la ciudad, bajo la mirada maternal de la policía y la dirección de expertos jefes de grupos. Una nueva mazorca y un nuevo candombe federal". 88

A partir de octubre, ...Antinazi intensificó su campaña en contra de Perón. En noviembre y diciembre apoyó la definitiva conformación de la Unión Democrática, a la que calificó como "un movimiento arrollador e incontenible" para lograr "el triunfo de la Democracia y la Libertad" y cerrarle el paso "al gran demagogo, al nefasto aprendiz de brujo, al corruptor de la ciudadanía". ${ }^{89}$ En este contexto, la publicación vio confirmados sus temores con el decreto que estableció el aguinaldo en el mes de diciembre, al cuál criticó como ilegal y destinado a "corromper y sobornar [...] la conciencia ciudadana de la clase obrera" y asegurar "la victoria nazi-peronista". 90

De esta manera, a fines de 1945 ...Antinazi se había transformado en el vocero de la Unión Democrática originalmente propuesta en las páginas de Argentina Libre. En esta negativa y cerrada percepción de Perón y su movimiento por parte del semanario y los grupos políticos e intelectuales que colaboraban en él pesaron distintos factores. Por un lado, el peronismo representaba un desafío concreto a las estructuras políticas, sociales e institucionales tradicionales, ahora en crisis pero enérgicamente defendidas en líneas generales por aquellos que colaboraban en ...Antinazi. En segundo lugar, la sinuosa trayectoria y los matices autoritarios del régimen militar y de Perón desde 1943 les dejaron poco espacio a estos grupos para la comprensión y negociación con el gobierno, y menos aún para llegar a un entendimiento con Perón. De cualquier manera, ...Antinazi y los sectores políticos y sociales representados en sus páginas mostraron un profundo desconocimiento de las transformaciones sociales experimentadas por el país en los años precedentes. Para ellos, Perón sólo representaba la encarnación de las amenazas totalitarias que Argentina Libre había denunciado y que ahora proyectaban sombras oscuras sobre el futuro del país. Como todo apoyo a Perón fue interpretado solamente como el resultado de la manipulación estatal de turbas oportunistas, ...Antinazi llegó a las elecciones de febrero de 1946 con un gran optimismo y convencido de la segura victoria de la Unión Democrática sobre el nazi-peronismo.

88 ...Antinazi 25 de octubre de 1945: 2. La bestialización de las masas peronistas también se puede consultar en los virulentos artículos de Eugenia Silveyra de Oyuela y José María Sáenz Valiente en el mismo número, páginas 4 y 5, y en el de Juan José Díaz de Arana,...Antinazi, 1 de noviembre de 1945: 1 y 6 . 


\section{Consideraciones finales: "Sueños de prosperidad y despertar miserable" 91}

Cuando la victoria de Perón en las elecciones fue confirmada, ...Antinazi reaccionó con una mezcla de incredulidad, tristeza, desilusión e ira contenida. A lo largo del mes de marzo, distintos artículos intentaron explicar las razones de un resultado tan catastrófico. Parecía como si el pueblo, "de memoria frágill, hubiera olvidado los hechos recientes. Las fuerzas armadas y el gobierno eran considerados como los principales responsables de haber llevado el país a ese resultado y de haber tolerado el fraude electoral que había permitido el triunfo de Perón -una acusación sin ningún tipo de fundamento. ${ }^{92}$ Éstas eran las únicas explicaciones posibles, dado que, como señalaba Eduardo Laurencena:

El número de sufragios obtenidos por el candidato nazi y su pandilla, si fuera el resultado de un proceso político normal, acusaría un extravío tan profundo del pueblo argentino, que habría que pensar en un fenómeno social de corrupción y de decadencia moral y espiritual irremediable.

En vistas de esta situación, Laurencena y otros colaboradores llamaban a continuar la lucha en el futuro, ya que "todo peronista es, justamente por ser peronista, nazi". ${ }^{93}$ Una versión de esta posición, que entrañaba conclusiones implícitamente más extremistas, encontró eco en otro largo artículo que criticaba a los partidos tradicionales por no haberse dado cuenta de que estaban frente a "un fenómeno difuso, incristalizable, inasible" y haber querido enfrentarlo con "métodos puramente políticos... No comprendieron que a una revolución se la debe combatir revolucionariamente, guerrilleramente, fuera de la normalidad de los comicios". ${ }^{94}$

Otros colaboradores intentaron interpretaciones más profundas y autocríticas del triunfo de Perón y el fracaso de los grupos de la Unión Democrática. Tal fue el caso de Augusto Durelli, quien exploró esos temas en un análisis que no dejaba de incluir los temas principales de la oposición antiperonista. Durelli no dudaba de que Perón era un demagogo y totalitario y que los beneficios de sus políticas de justicia social eran más aparentes que reales. Sin embargo, reconocía que:

Después de quince años de esterilidad legislativa se desarrolló el régimen jubilatorio y se aumentaron los salarios, se implantó el estatuto del peón, alquileres y

91 Título de un artículo de Juan Antonio Solari, ...Antinazi 14 de marzo de 1946: 1 y 6. 
arrendamientos fueron congelados. El aguinaldo, en fin, y el anuncio de la participación en las ganancias fueron más que suficientes para entusiasmar a los obreros.

Según Durelli, el éxito de Perón fue posible en gran parte gracias a los errores de los dirigentes políticos que se le opusieron. En primer lugar, erraron profundamente en ver a los partidarios de Perón como "turbas pagadas y elementos de bajo fondo" en vez de lo que realmente eran, "una gran masa de pobre gente que con toda buena fe salía a la calle a defender su salvador". Además, Durelli cargó contra la "ignorancia de dirigentes que creyeron que bastaban elecciones sin fraude material para suprimir el fascismo" y que "no vivían con el pueblo". Para Durelli, el problema fundamental ignorado por la oposición y que explicaba el triunfo de Perón era que "gran parte del electorado carece de las más elementales nociones de cultura política y toma todavía las mentiras de la demagogia por verdades de apóstoles". El liberalismo político y filosófico del siglo XIX había establecidos las bases formales de la educación, pero tanto las escuelas como los maestros no se habían preocupado por enseñarle al pueblo a "ser ciudadano", "ejercitar sus inalienables derechos humanos" y el significado y obligaciones de la ciudadanía y la democracia". ${ }^{95}$

Más allá de las diferentes interpretaciones, no hay dudas de que el semanario y sus colaboradores coincidían en que la victoria de Perón exigía la continuación de la lucha en contra de lo que percibían, desde su posición ideológica y política, como un régimen antidemocrático. En este sentido, ...Antinazi continuó su campaña contra el gobierno, exigiendo respeto hacia las libertades políticas y económicas. Sin embargo, las energías de la publicación parecen haber mermado significativamente con la derrota de la Unión Democrática. En junio de 1946 cambió su nombre a Argentina Libre, y su constante oposición a Perón le ganó la hostilidad del gobierno. En agosto de 1947, anunció que la policía había allanado sus oficinas y encarcelado a su editor, Guillermo Korn. ${ }^{96}$ El 9 de octubre, Argentina Libre publicó su último número consecutivo, el 297, que revela el volumen y la trayectoria de la publicación desde sus orígenes en marzo de 1940.

De acuerdo a la información suministrada por el CEDINCI, el director, Koiffman, fue deportado y se intentó lanzarlo nuevamente bajo el título de Ética, que fue clausurado tras publicar un único número. El último intento de publicación, de nuevo bajo el título Argentina Libre, se realizó entre agosto de 1948 y mayo de 1949 en Montevideo, desde donde se ingresaba clandestinamente a la Argentina. (CEDINCI 2002: 3). Sin embargo, en esta etapa de clan- 
destinidad ya era un pálido reflejo de sus épocas anteriores, lo que se refleja en su formato reducido, el menor número de colaboraciones y el carácter anónimo de muchas de ellas. En parte, esta declinación puede reflejar los reajustes políticos e ideológicos generados por el peronismo en el poder y la dificultad de la publicación para adaptarse a la nueva situación. Lo cierto es que con el último número de mayo 1949, se extinguía definitivamente una experiencia editorial de vital importancia para la consolidación de los lazos personales, sociales, políticos e ideológicos del arco antifascista y antiperonista entre 1940 y 1946.

\section{Bibliografía y fuentes citadas}

Argentina Libre/...Antinazi, 1940-1949.

Bejar, María Dolores (1983): Uriburu y Justo: el auge conservador, 1930-1935. Buenos Aires: CEAL.

Bisso, Andrés (2001): "La recepción de la tradición liberal por parte del antifascismo argentino". En: Estudios Interdisciplinarios de América Latina y el Caribe, 12, 2, pp. 85-113.

Bitrán, Rafael/Schneider, Alejandro (1991): El gobierno conservador de Manuel A. Fresco en la provincia de Buenos Aires, 1936-1940. Buenos Aries: CEAL.

Boletín de la Sociedad Argentina de Escritores (SADE), (1938), (1944) у (1946).

Buchrucker, Christian (1987): Nacionalismo y peronismo: la Argentina en la crisis ideológica mundial, 1927-1955. Buenos Aires: Sudamericana.

Cantón, Darío/Moreno, José L./Ciria, Alberto (1986): La democracia constitucional y su crisis. Buenos Aires: Hyspamérica.

Cattaruzza, Alejandro (1993): "Algunas reflexiones sobre el revisionismo histórico". En: Devoto, Fernando (ed.), La historiografia argentina en el siglo XX, Vol. 1. Buenos Aires: CEAL, pp. 113-139.

- (1997): Marcelo T. De Alvear. Buenos Aires: Fondo de Cultura Económica.

Centro de Documentación e Investigación de la Cultura de Izquierdas en la Argentina (CEDINCI) (2002): Publicaciones politicas y culturales argentinas (c. 1917-1956). Catálogo de microfilms. Buenos Aires: CEDINCI.

Ciria, Alberto (1985): Partidos y poder en la Argentina contemporánea, 1930-1943. Buenos Aires: Hyspamérica.

De Privitellio, Luciano (1997): Agustín P. Justo. Las armas en la política. Buenos Aires: Fondo de Cultura Económica.

- (2001): "La política bajo el signo de la crisis". En: Cattaruzza, Alejandro (ed.): Nueva historia argentina VII.- Crisis económica, avance del estado e incertidumbre política, 1930-1943. Buenos Aires: Sudamericana, pp. 97-142.

Diario de Sesiones de la Cámara de Senadores (1935) y (1936).

Di Tella, Guido/Watt, D. Cameron. (eds.) (1989): Argentina between the great powers, 1939-1946. London: Macmillan and St. Anthony's College. 
Dolkart, Ronald (1993): “The right in the Década Infame”. En: McGee Deutsch, Sandra/Dolkart, Ronald (eds.): The Argentine right. Its history and intellectual origins, 1910 to the present. Wilmington: Scholarly Resources, pp. 65-98.

Falcoff, Mark (1982): “Argentina”. En: Falcoff, Mark / Pike, Frederick (eds.): The Spanish Civil War, 1936-1939. American Hemispheric Perspectives. Lincoln: University of Nebraska Press, pp. 291-348.

Fitte, Rodolfo / Sánchez Zinny, E. F. (1944): Génesis de un sentimiento democrático. Buenos Aires: Imprenta López.

García, Marcela (1995): “Elecciones y partidos políticos en la Argentina. La formación de la Unión Democrática". En: Malamud, Carlos (ed.): Partidos políticos y elecciones en América Latína y la Península Ibérica, 1830-1930, II, Madrid: Instituto Ortega y Gasset, pp. 72-76.

Goldar, Ernesto (1996): Los argentinos y la Guerra Civil Española. Buenos Aires: Plus Ultra.

Halperin Donghi, Tulio (1970): El revisionismo histórico argentino. Buenos Aires: Siglo XXI.

- (2000): La democracia de masas. Buenos Aires: Paidós.

- (2003): La Argentina y la tormenta del mundo. Buenos Aires: Siglo XXI.

- (2004): La república imposible. Buenos Aires: Ariel.

Hechos e Ideas. Revista Radical (Buenos Aires).

La Prensa (Buenos Aires).

La Vanguardia (Buenos Aires).

Macor, Darío (2001): "Partidos, coaliciones y sistemas de poder". En: Cattaruzza, Alejandro (ed.): Nueva historia argentina VII. Crisis económica, avance del estado e incertidumbre politica, 1930-1943. Buenos Aires: Sudamericana, pp. 49-94.

Nállim, Jorge (2002): The Crisis of Liberalism in Argentina, 1930-1946. Tesis doctoral inédita. University of Pittsburgh.

- (2003): "De los intereses gremiales a la lucha política: la Sociedad Argentina de Escritores (SADE), 1928-1946”. En: Prismas. Revista de Historia Intelectual, 7, pp. 117-138.

Newton, Ronald (1995): El cuarto lado del triángulo. La amenaza "nazi” en Argentina. Buenos Aires: Sudamericana.

Pereyra, Enrique (1976): "La Guerra Civil Española en Argentina". En: Todo es Historia, 110, pp. 6-33.

Potash, Robert (1982): El ejército y la politica en la Argentina, 1928-1945. Buenos Aires: Sudamericana.

Quattrocchi-Woisson, Diana (1995): Los males de la memoria. Historia y política en la Argentina. Buenos Aires: Emecé.

Quijada, Mónica (1991): Aires de república, aires de cruzada: la Guerra Civil Española en Argentina. Barcelona: Sendai.

Rapoport, Mario (1980): Gran Bretaña, Estados Unidos y las clases dirigentes argentinas, 1940-1945. Buenos Aires: Editorial de Belgrano.

Reitano, Emir (1992): Manuel Fresco, antecedente del gremialismo Peronista. Buenos Aires: CEAL. 
Rock, David (1993): La Argentina autoritaria. Los nacionalistas, su historia y su influencia en la vida pública. Buenos Aires: Ariel.

Romero, Luis Alberto (1999): Breve historia contemporánea de la Argentina. Buenos Aires: Fondo de Cultura Económica.

Rouquié, Alain (1981): Poder militar y sociedad politica en la Argentina, 1928-1943. Buenos Aires: Emecé.

Ruiz Jiménez, Laura (1994): Estados Unidos y Gran Bretaña en la prensa argentina. Tesis doctoral inédita. Madrid: Instituto Ortega y Gasset, Universidad Complutense de Madrid.

Scenna, Miguel Ángel (1984): FORJA. Una aventura argentina. De Yrigoyen a Perón. Buenos Aires: La Bastilla.

Schwarztein, Dora (2001): Entre Franco y Perón. Memoria e identidad del exilio republicano español en Argentina. Madrid: Crítica.

Senkman, Leonardo (1995): "El nacionalismo y el campo liberal argentinos ante el neutralismo: 1939-1943”. En: Estudios Interdisciplinarios de América Latina y el Caribe, 6, 1, pp. 23-49.

Sociedad Argentina de Escritores (SADE) (1941): "III Congreso De Escritores. Tucumán 1941. Resoluciones, Declaraciones y Conferencias.” Buenos Aires: SADE.

Svampa, Maristella (1994): El dilema argentino. Civilización o barbarie. De Sarmiento al revisionismo peronista. Buenos Aires: El Cielo por Asalto.

Torre, Juan Carlos (1990): La vieja guardia sindical y Perón. Sobre los orígenes del peronismo. Buenos Aires: Sudamericana.

Trifone, Víctor/Svarzman, Gustavo (1993): La repercusión de la Guerra Civil Española en la Argentina, 1936-1939. Buenos Aires: CEAL.

Zanatta, Loris (1997): Del estado liberal a la nación católica. Ejército e Iglesia en los orígenes del Peronismo, 1930-1943. Buenos Aires: Universidad de Quilmes.

- (2000): Perón y el mito de la nación católica. Iglesia y ejército en los orígenes del Peronismo. Buenos Aires: Sudamericana.

Zuleta Álvarez, Enrique (2001): "Los gobiernos de la Concordancia". En: Academia Nacional de la Historia, Nueva Historia-VII-La Argentina del Siglo XX, c. 19141943. Buenos Aires: Planeta, pp. 265-297. 